\title{
GEREJA KATOLIK INDONESIA DI TENGAH PUSARAN POLITIK KEKUASAAN DAN TANTANGANNYA KE DEPAN
}

\author{
D onatus Sermada K.
}

STFT W idya Sasana M alang

\begin{abstract}
A bstract:
This article was in fact a lecture delivered by the author on June $10^{\text {th }}, 2018$ in Surabaya during the national Seminar touching on the Catholic Church in Indonesia and the actual Indonesian political Situation called "Tahun Politik" (Political Year). The author spoke about the Indonesian Catholic Church in themidst of Indonesian political struggleand the futurechallenges the Catholic Church should face. There were three social-political Phenomenons that have damaged and are still damaging the life of Indonesian nation, including the Indonesian Catholic church, namely the complicated birocratization; the unhealthy politization of the religion and the demoralization of the law. These phenomenons should be taken into account by the Catholic Church, when it comes to concrete commitment of the Catholic Church to give positive impact on Indonesian society based on its own Catholic faith.
\end{abstract}

Key Words: Politic, Chatholic Church, Bureaucratization, Politicization, De moralization

\begin{abstract}
A bstrak:
Artikel ini pada kenyataannya adalah ceramah yang dibawakan penulis pada tanggal 10 Juni 2018 di Surabaya pada kesempatan Seminar Nasional yang bertemakan tentang Gereja Katolik Indonesia dan Situasi aktual politik Indonesia yang disebut "Tahun Politik". Penulis berbicara tentang Gereja Katolik Indonesia di tengah pergulatan politis dan tantangan-tantangan yang harus dihadapi gereja Katolik ke depan. Ada tiga fenomen sosial-politis yang telah mencederai dan masih sedang mencederai kehidupan berbangsa, termasuk Gereja Katolik, yaitu birokratisasi yang rumit; politisasi yang tidak sehat terhadap agama dan demoral isasi hukum. Fenomen-fenomen itu perlu disikapi gereja Katolik, bila gereja Katolik berkomitmen dalam terang iman Katolik untuk menjawabi tantangan-tantangan itu secara positif demi kebaikan bersama masyarakat Indonesia.
\end{abstract}

Kata-kata Kunci :Politik; Gereja Katolik; Birokratisasi; Politisasi; Demoralisasi. 


\section{Pendahuluan}

Gereja Katolik Indonesia adalah masyarakat sosial-politis yang beriman katolik di Indonesia menurut pendekatan ilmu sosial. Struktur sosial gereja Katolik di Indonesia dan proses penyelenggaraan kekuasaan bisa dicermati atas data-data empiris. Ketika dikaitkan dengan situasi sosial-politis aktual bangsa Indonesia, Gereja Katolik seperti kelompok sosial yang lain di Indonesia dicederai oleh fenomen-fenomen sosial-politis, yaitu birokratisasi yang rumit di segala bidang kehidupan; politisasi yang tidak sehat terhadap agama dan demoralisasi hukum. Tantangan terhadap gereja Katolik Indonesia kedepan terletak dal am dampak negatif tiga fenomen itu yang sudah melekat kuat dalam diri masyarakat Indonesia, termasuk orang-orang Indonesia yang katolik. Tantangantantangan itu yang berasal baik dari dalam tubuh gereja Katolik sendiri maupun dari luar gereja Katolik tentu menuntut kebijakan-kebijakan jelas gereja Katolik Indonesia dalam komitmennya untuk menjawabi tantangan-tantangan tersebut.

\section{Gereja Katolik Indonesia: Suatu Pendekatan Sosio-Politis}

Gereja Katolik Indonesia dalam peneropongan ilmu sosial merupakan suatu realitas sosial-religius di bumi Indonesia. Sebagai sebuah realitas sosial, dia tidak berbeda dengan persekutuan atau organisasi masyarakat yang lain, tetapi karakter religius yang melekat pada persekutuan itu membedakan persekutuannya dengan persekutuan yang lain. Karakter religius itu tampak jelas dalam karakter "katolik", yaitu persekutuan manusia yang beriman katolik. Jadi, gereja katolik di Indonesia adalah persekutuan manusia yang beriman katolik di tanah Indonesia. Dalam bahasa sederhana, gereja katolik di Indonesia adalah masyarakat Katolik Indonesia, atau bila menekankan sisi "Indonesia", gereja katolik Indonesia adalah masyarakat Indonesia yang Katolik.

Pemahaman tersebut sama sekali tidak terkait dengan pemahaman iman yang menyoroti hakekat gereja katolik dalam perspektif teologis dan eklesiologis. Sebagai suatu persekutuan manusia atau masyarakat, gereja katolik di Indonesia memiliki struktur sosial tertentu yang di dalamnya terjadi mobilitas sosial dan penyelenggaraan kekuasaan. ${ }^{1}$ Struktur sosial gereja katolik di Indonesia terbentuk dari tiga lapisan sosial: Klerus (Uskup, imam, diakon); biarawan-biarawati; awam. Dalam konteks masyarakat Indonesia, jumlah orang katolik sangat kecil. Tahun 2013 jumlah umat katolik 6,9 juta (termasuk kaum klerus) dari penduduk Indonesia 248,8 juta. Dalam prosentase, hanya 2,9\% dari seluruh jumlah

1 Bdk. Friedrich Fuerstenberg, Soziologie. Berlin: Walter de Gruyter, 1978, hlm.121-131. 
penduduk Indonesia pada tahun itu adalah orang katolik. Tahun 2016 jumlah umat katolik Indonesia mencapai sekitar 7 juta dari penduduk Indonesia 258,7 juta (3\% umat katolik). Di dalam prosentase yang kecil ini, terdapat 37 keuskupan di Indonesia, dan 1205 paroki. Di Pulau Jawa sendiri terdapat 7 keuskupan dan 295 paroki. Di dalam tiga lapisan sosial besar (klerus, biarawan-biarawati; awam), masih lagi ada unit-unit sosial kecil di dalam kelompok sosial itu. Misalnya, di kalangan klerus ada unitunit sosial imam yang berasal dari berbagai macam organisasi dan serikat: imam projo; imam CM ; imam ordo Carmel; imam SVD, imam Don Bosco; imam Dominikan; imam Yesuit dsb. Di kalangan biarawan-biarawati ada juga berbagai macam serikat religius baik pria maupun perempuanseperti serikat biarawati yang menempati keuskupan Surabaya, yaitu Sustersuster Ssps, Suster CB, para suster PRR, para suster Claris, para suster CIJ dsb. Di kalangan awam pun terdapat unit-unit sosial di dalam kehidupan berparoki, seperti Kaum Muda Katolik, Organisasi ME, Organisasi Tulang Rusuk, Legio Maria, PMKRI, Kaum Lansia dan sebagainya. Semakin banyak jumlah anggota sebuah persekutuan sosial, semakin terbagi persekutuan sosial itu ke dalam unit-unit sosial yang Iebih kecil seperti komunitas-komunitas. Itu adalah suatu hal yang lumrah dalam proses perkembangan evolutif suatu masyarakat. Habermas menyebutnya "proses diferensiasi sosial" yang mencerminkan dinamika hidup suatu masyarakat. ${ }^{2}$

Ketika berbicara tentang Tahun Politik yang berhubungan erat dengan Politik Kekuasaan di Indonesia, ada dua fenomena sosial yang sedang dialami oleh masyarakat Katolik Indonesia, yaitu mobilitas sosial di dalam tubuh gereja Katolik dan politik kekuasaan di dalam tubuh gereja Katolik sendiri. Mobilitas sosial berarti perpindahan gerak sosial baik dalam arti tempat maupun dalam arti posisi atau kedudukan. ${ }^{3}$ Dalam arti tempat, umat Katolik yang berada di sebuah paroki di kota besar, pada umumnya bukanlah umat Katolik dari penduduk asli di paroki itu, tapi berasal dari daerah lain di luarnya, seperti umat Katolik di paroki Wonokromo berasal dari daerah yang berbeda-beda di Indonesia (dari Jawa Tengah, dari NTT, dari Kalimantan dII). Dalam arti posisi dan kedudukan, mobilitas sosial terjadi bukan karena soal keyakinan katolik yang membuat orang-orang Katolik berpindah tempat, tapi karena tuntutan hidup yang mendorong mereka untuk berpindah tempat, seperti adanya lapangan kerja, tuntutan profesi, peroleh hidup yang lebih layak di tempat baru dan Iain-lain. Dengan adanya mobilitas sosial baik dalam arti tempat maupun dalam arti posisi atau kedudukan, umat katolik di

2 Juergen Habermas, The Theory of Communicative A ction. V olume Two. Lifeworld System: Critique of Functionalist Reason. Boston: Beacon Press, 1989, hlm. 165-166.

3 Friedrich Fuerstenberg, Soziologie... . Op.Cit., 121-124. 
sebuah paroki sudah berwajah plural, karena berasal dari suku, ras, bahasa, status sosial serta latar belakang keyakinan tradisional yang berbeda-beda. Mobilitas sosial seperti yang dilukiskan itu bersifat horizontal. Artinya gerak sosial entah dalam arti tempat atau dalam arti posisi dan kedudukan berjalan dalam tataran interaksi sosial baik interaksi sosial antara umat katolik sendiri maupun antara umat katolik dengan kel ompok sosial yang bukan katolik. M obilitas sosial yang bersifat vertikal berjalan dalam kaitannya dengan kuat-lemahnya iman katolik yang dihayati, berkaitan dengan seberapa kuatnya pengaruh ajaran iman katolik terhadap hidup umat katolik, berkaitan dengan rajin-tidaknya praktek hidup iman katolik. ${ }^{4}$ Secara matematis, kita tidak bisa mengukurnya, tetapi beberapa gejala lahiriah dapat menjadi indikasi terhadap kwalitas iman katolik seseorang. Orang Katolik yang awalnya rajin ke gereja dan saleh tiba-tiba tidak lagi pergi ke gereja, karena tidak lagi mengalami Allah dalam hidupnya (Katolik KTP), tetapi juga ada orang katolik yang tidak pernah ke gereja tiba-tiba rajin ke gereja oleh karena pengalaman akan rahmat Allah dalam hidupnya. A da juga orang katolik yang pindah agama baik pindah ke gereja-gereja protestan atau pun pindah masuk agama Islam atau Buddha. Ada juga umat katolik yang tidak merasa terikat pada kehidupan paroki di mana dia berada. Mereka lebih suka merayakan hari minggu atau pesta-pesta besar gerejani bukan di parokinya tetapi di paroki lain. Ada umat katolik yang lebih suka berziarah ke tempat-tempat ziarah seperti ke gua-gua Maria di tempat lain dari pada berdoa di tempat ziarah seperti di gua Maria di parokinya. Itulah mobilitas sosial masyarakat katolik dalam dimensi vertikal. ${ }^{5}$

Dalam hal penyelenggaraan kekuasaan di dalam tubuh gereja Katolik, kekuasaan yang disandang umat katolik, apapun bentuk kekuasaan itu, berada di bawah suatu semangat yang sama (spiritual itas kekuasaan), yaitu M ELAYAN I. A dapun bentuk kekuasaan itu bermacammacam. A da kekuasaan yang bersifat ekslusif, yaitu milik kel ompok sosial tertentu seperti kekuasaan klerus dalam hal melayani sakramen-sakramen, dan ada kekuasaan yang bersifat terbuka atau inklusif, yaitu mendapat kewenangan untuk menjabat tugas tertentu, seperti kewenangan para dewan paroki, kewenangan guru katolik, kewenangan pemimpin organisasi-organisasi katolik, kewenangan Bimas Katolik yang menjadi penghubung antara gereja Katolik dan pemerintah Indonesia, kewenangan tokoh-tokoh katolik yang mengambil bagian dalam pemerintahan seperti ada tiga menteri Katolik dalam Kabinet Kerja

4 Bdk. Friedrich Fuerstenberg, Kirchenform und G esellschaftsstruktur. Dalam Religionssoziologie. Soziologische T exte. F. Fuerstenberg (Hrg.). Berlin: Hermann Luchterhand Verlag, 1970, hlm. 288-289.

5 Friedrich Fuerstenberg, Soziologie...Op.cit., hlm. 125-131. 
Pemerintahan Jokowidodo, dan rupa-rupa kewenangan lain yang bisa dipegang oleh kaum awam. Hal yang khas dalam gereja Katolik, termasuk gereja Katolik di Indonesia, adalah kekuasaan yang bersifat hirarkis untuk menunjukkan keterkaitan masyarakat katolik Indonesia dengan masyarakat Katolik sedunia. Kekuasaan yang bersifat hirarkis itu tampak pada pemimpin tertinggi yang kelihatan dari gereja katolik, yaitu Paus di Roma (Paus Fransiskus) dan dutanya di Indonesia, dan di bawahnya ada para uskup Indonesia, dan di bawahnya lagi para pastor paroki dan umat paroki. Para uskup Indonesia membangun satu gremium atau konferensi yang disebut KWI (Konferensi Wali Gereja Indonesia); mereka bersama-sama memperhatikan kepentingan umat Katolik Indonesia. Penyelenggaraan kekuasaan di dalam tubuh gereja Katolik di Indonesia sudah diatur rapi dengan sifat-sifat seperti yang dilukiskan itu.

\section{Pusaran Politik Kekuasaan Di Indonesia}

Bangsa Indonesia yang di dalamnya masyarakat Katolik merupakan bagian hakiki dari NKRI sedang berada dalam pusaran politik kekuasaan yang mencekam. Kekuasaan berarti sebuah kesempatan yang digunakan oleh subyek tertentu untuk meloloskan kehendak sendiri untuk dipenuhi oleh orang Iain dalam relasi sosial. ${ }^{6}$ Kehendak yang diloloskan ini dilakukan baik oleh orang perorangan (kehendak individual) maupun oleh kelompok sosial tertentu (kehendak bersama) dengan menuntut orang lain, agar orang lain memenuhi kehendak mereka.

Berbicara tentang politik kekuasaan, perlu dibuat distingsi lebih dahulu antara politik kekuasaan dan kekuasaan politik. Makna keduanya berbeda. Politik kekuasaan berarti kebijakan atau strategi untuk meraih kekuasaan demi kebaikan bersama (bonum commune) atau kesejahteraan bersama, sementara kekuasaan politik berarti kesempatan untuk berpolitik, peluang yang dimiliki oleh seseorang atau sekelompok orang untuk menjalankan kegiatan politikmenuju pencapaian kebaikan bersama. Aristoteles berbicara tentang politik dalam kaitannya dengan Negara sebagai suatu persekutuan yang dibentuk untuk mewujudkan kebaikan bersama atau kesejahteraan bersama (Bonum Commune). Orang yang berpolitik adalah pemerintah, penguasa, pemimpin, yang menjalankan kehidupan bernegara atau bermasyarakat menuju perwujudan kesejahteraan bersama. ${ }^{7}$

Pusaran politik kekuasaan yang mencekam di Indonesia memaksudkan percaturan politik kekuasaan yang membahayakan

6 Dirk Kaesler, $M$ ax W eber Eine Einfuehrung in Leben, W erk und Wirkung. Frankfurt: Campus Verlag, 1995, hlm. 207-208.

7 Aristotle, The Politics. London: Penguin Books, 1992, hlm. 53-55. 
kehidupan bersama dalam kehidupan bernegara dan bermasyarakat di Indonesia. A pa yang dipercaturkan? Yang dipercaturkan adalah strategistrategi atau kebijakan-kebijakan entah untuk merebut kekuasaan entah untuk mempertahankan kekuasaan, dan kebijakan atau strategi tersebut tampak berbahaya. Di bawah ini disebut tiga fenomena kebijakan yang sedang mencederai kehidupan berbangsa dan bernegara. Gereja Katolik bersama masyarakat lain dalam NKRI mengalami pencederaan itu. Tiga fenomena itu adalah birokratisasi yang mencekik; politisasi agama; demoralisasi hukum. Ketika dikaitkan dengan kekuasaan, maka kekuasaan di bidang eksekutif (presiden, para menteri, gubernur, bupati, camat hingga kepala desa), di bidang legislatif (DPR dari tingkat pusat hingga tinggkat daerah) dan di bidang yudikatif (semua instansi penegak hukum: MA, Mahkamah Konstitusi, kepolisian, pengadilan tinggi hingga pengadilan daerah) sudah dan sedang berada dalam cengkeraman tiga fenomena itu. Dengan kata Iain, kekuasaan yang dijalankan sedang terjebak dalam tiga fenomena itu.

\section{Birokratisasi yang mencekik}

Birokratisasi berarti suatu proses pembentukan wadah, institusi, struktur organisasi dan proses penyelenggaraan institusi atau organisasi tersebut. Di Indonesia, birokratisasi menimpa semua bidang kehidupan bernegara dan bermasyarakat. Tiga bidang kekuasaan, yaitu kekuasaan legislatif, eksekutif dan yudikatif, sedang mengalami proses birokratisasi. Misalnya, birokratisasi pendidikanadalah proses pembentukan wadah, institusi, struktur organisasi pendidikan, proses penyelenggaraan pendidikan baik dari tingkat rendah sampai ke perguruan tinggi. Birokratisasi Pendidikan berada di bawah tanggung jawab Negara, dan dalam hal ini berada di bawah kementerian pendidikan dan kebudayaan. Kementerian ini merupakan bagian dari kekuasaan eksekutif dalam sistem kekuasaan Negara Indonesia.

Sebelum tahun 2014 pendidikan tinggi di Indonesia baik pendidikan tinggi negeri maupun pendidikan tinggi swasta berada di bawah satu kementerian, yaitu kementerian pendidikan dan kebudayaan, tetapi sejak tahun itu, pendidikan tinggi di Indonesia berada di bawah kementerian tersendiri yang bertanggung jawab terhadap presiden, yaitu kementerian Riset, Tekhnologi dan Pendidikan Tinggi (Kemenrisetdikti). Kementerian ini membawah 10 wadah dalam struktur kelembagaannya: Sekretariat Jenderal; direktorat pembelajaran dan kemahasiswaan; direktorat jenderal kelembagaan ilmu pengetahuan Tekhnologi dan Pendidikan Tinggi dsb. Sementara itu, kementerian Pendidikan dan Kebudayaan (Kemendikbud),yang mengurus pendidikan sejak anak usia dini hingga ke pendidikan Menengah menurut peraturan kementerian Pendidikan dan Kebudayaan No. 11 Tahun 2015, memiliki Unit Pelaksana Tekhnis 
(TPS) yang terdiri dari enam unit: Sekretariat jenderal; Direktorat Jenderal Pendidikan anak Usia dini dan pendidikan masyarakat; Direktorat Jenderal Guru dan tenaga kependidikan, dsb. Dua lembaga yang terpisah itu, yaitu Kemendikbud dan Kemenrisetdikti, berada bersama dengan lembaga-lembaga pendidikan yang sudah ada, yaitu lembaga pendidikan swasta; lembaga pendidikan negeri; KOPERTIS (Koordinasi Perguruan Tinggi Swasta) yang menjadi penghubung antara lembaga pendidikan tinggi swasta dan pemerintah (Kemenrisetdikti). Dalam kurun waktu hingga saat ini, terdapat juga pendidikan kedinasan seperti kementerian keuangan, kementerian hukum dan HAM, kementerian agama yang mencakup pendidikan tinggi yang kurikulumnya bermuatan agama, kementerian kesehatan yang menangani pendidikan yang berhubungan dengan kesehatan, dan sebagainya. Pendidikan Indonesia yang bertujuan untuk membentuk manusia Indonesia yang Pancasilais seperti yang dirumuskan dalam Undang-Undang Pendidikan Nasional tahun 2003 diselenggarakan dalam wadah dan instansi yang bermacam ragam, tetapi modal pembiayaan beroperasinya instansi-instansi itu berasal dari sumber yang sama, yaitu $20 \%$ dari Anggaran Pendapatan dan Belanja Negara (APBN).

Dengan adanya instansi-instansi resmi pendidikan yang bermacammacam, modal $20 \%$ yang diambil dari APBN dengan sendirinya dibagibagi ke instansi-instansi itu. Proses pembagian ini adalah proses alokasi dana untuk kepentingan beroperasinya instansi-instansi itu. Dalam Iaporan Kompas dan Media Sosial, anggaran pendidikan tahun 2018 sebesar Rp. 444,131 Triliun (20\% dari APBN), dan dari padanya Kementerian Agama yang menyelenggarakan pendidikan mendapat porsi yang lebih besar, yaitu 52,681 Triliun. ${ }^{8}$ Proses birokratisasi di bidang pendidikan tidak lain dari pada proses akumulasi modal $20 \%$ pada tangan penyelenggara instansi-instansi pendidikan itu. Karena itu, untuk kepentingan kantor dan urusan administratiflah terserap modal induk yang terbagi-bagi itu, dan sedikit sekali untuk kepentingan realitas pendidikan di lapangan. Celah korupsi sangat besar, karena pengelola dana cairan dari pusat berada di tangan penguasa yang mendapat wewenang khusus untuk menerapkan kebijakan-kebijakan, bahkan instansi-instansi kecil apa pun di bawah instansi induk memiliki kebijakan dan strategi-strategi tertentu untuk memanfaatkan alokasi dana yang diperuntukkan bagi instansi-instansi kecil itu.

Birokratisasi di bidang pendidikan seperti tersebut di atas hanyalah contoh kecil dari birokratisasi di bidang-bidang Iain di Indonesia. Kementerian agama sendiri yang terdiri dari banyak instansi, bila

8 www.google.co.id APBN 2018: Total Anggaran Pendidikan Rp444.131 Trilliun. Diakses ulang pada tanggal 17 Oktober $2018 \mathrm{Pk} .19 .00$. 
dikaitkan dengan alokasi modal untuk penyelenggaraannya mendapat dua porsi dari APBN, yaitu dari instansi pendidikan agama dan dari instansi kementerian agama itu sendiri. Yang menarik untuk disimak ialah bahwa mengapa dikatakan proses birokratisasi yang terjadi di Indonesia itu bersifat "mencekik". Dikatakan "mencekik", karena beban administratif-prosedural terlalu banyak dan melampaui kapasitas tugas profesionalnya. Rakyat dan para petugas di lapangan dicekoki oleh berbagai macam syarat dan tuntutan procedural-administratif, karena setiap instansi, betapapun kecil unitnya, mempunyai kebijakan dan strategi sendiri untuk menerapkan kebijakan dari pusat. Mentalitas bangsa kita tertanam begitu kuat dalam pola tingkah laku yang lebih menekankan prosedur dan administrasi dari pada kebutuhan pokok yang harus dipenuhi. Contoh, ketika disebut "bertambahnya beban administratif pada guru" dalam artikel kompas "Pendidikan Belum 0 ptimal" (Kompas, Senin 30 A pril 2018), Caroline Mindo, seorang guru Biologi SMAN 4 Depok, Jawa Barat, mengeluh bahwa tugas mengajar 40 jam per minggu diperberat dengan beban administrasi. Dampaknya terhadap para guru Katolik yang adalah pegawai negeri sipil tetapi bekerja pada sekolah swasta tentu sangat parah, karena mereka harus mengabdi pada dua tuan: pemerintah dengan kebijakannya dan gereja katolik dengan kebijakannya.

Birokratisasi yang mencekik tidak punya hubungan langsung dengan percaturan politik kekuasaan yang memanas pada tahun politik ini. Tetapi frasa "ganti menteri, ganti kebijakan" yang dialami oleh masyarakat akar rumput, misalnya sehubungan dengan perubahan kurikulum pendidikan yang begitu cepat (sudah tiga kali perubahan kurikulum dalam masa reformasi:2004; 2006; 2013), masih tetap menggema di dalam hati rakyat. Kekuasaan masih merupakan kesempatan untuk menghasilkan dan menerapkan kebijakan-kebijakan atas dasar kepentingan mereka yang memegang kekuasaan (penguasa). Proses birokratisasi adalah proses penciptaan peluang dan kesempatan untuk melembagakan kebijakankebijakan yang membawa keuntungan bagi penguasa.

\section{Politisasi yang tidak sehat terhadap agama}

Politisasi agama berarti proses mempolitikan agama atau proses menjadikan agama sebagai alat politik untuk mencapai kekuasaan. Perlu disadari bahwa agama dan politik tentu berbeda, tetapi berhubungan satu sama lain. Perbedaannya terletak dalam esensi keduanya yang berbeda. A gama pada dasarnya adalah rahmat, hadiah, yang berasal dari luar manusia tapi menyentuh batin terdalam manusia secara pribadi untuk percaya dan memberi respons terhadapnya. Agama dari sananya terpisah dari etika. Bahasa teologis menyebut agama sebagai "rahmat Allah atau pengalaman akan Allah". Manusia yang mengalami ini adalah 
manusia yang percaya akan Allah dan berada dalam disposisi merasa damai, aman, tenang, terlindung, bahagia, penuh syukur, takwa, berhati murni dan jujur, dan hal-hal bajik lainnya. Para mistisi dan kaum Sufi mencerminkan esensi agama secara transparan dalam hidup mereka. Karena rahmat itu tidak dialami oleh satu individu saja, maka agama dari esensinya tidak bersifat pribadi semata-mata, tetapi menjadi milik kollektif yang berasal dari sumber yang sama, yaitu pengalaman rahmat bersama dengan disposisi humanis yang sama. Perbedaan agama adalah satu keniscayaan, karena respons subyek terhadap rahmat itu berasal dari subyek historis yang berbeda-beda selaku ruang dan waktu penampakan dari "Yang Kudus" (Mircea Eliade). ${ }^{9}$ Bahasa teologis menyebut "Yang Kudus" sebagai "Allah".

Politik pada dasarnya adalah strategi, kebijakan manusia untuk kebaikan bersama (bonum commune), untuk kesejahteraan dan kemaslahatan bersama dan bukan untuk kepentingan golongan dan kepentingan ideologi tertentu. Kata bahasa Arab yang sudah menjadi kata baku bahasa Indonesia dengan tepat menyebut politik sebagai "siasat". Politik berada dalam rana etika dan terpisah dari rana agama. Ketika politik bersentuhan dengan agama, politik hendaknya dijalankan atas dasar kebijakan dan strategi yang menjadikan agama yang dianutinya sebagai "rahmat atau hadiah" untuk penganut agama Iain. Inilah letak politisasi yang sehat terhadap agama. Itu berarti bahwa dengan disposisi humanis yang dialami dalam agama, kebijakan dan strategi yang hendak diterapkan dalam aksi-aksi politis haruslah bertujuan untuk mencapai kesejahteraan dan kebaikan bersama dan bukannya kebijakan dan strategi untuk merebut kekuasaan dengan aksiaksi praktis. Itulah letak etika berpolitik sesungguhnya, bila politik hendak dijiwai oleh nilai-nilai religius dalam relasi antara politik dan agama.

Kenyataan di Indonesia menunjukkan bahwa relasi antara agama dan politik rancu dan tak seimbang. Kerancuan dan ketidakseimbangan relasi itu terletak dalam etika beragama dan etika berpolitik. Para pelaku kedua bidang ini saling menunggang untuk kepentingan dan tujuan masing-masing. Para penganut agama, teristimewa para tokoh agama dan pemuka agama, beroperasi di rana politik untuk kepentingan agama, seperti yang terjadi dalam pemerintahan teokratis (N egara agama), di mana para pemimpin spiritual menjabat juga sebagai tokoh politik yang berkuasa. Di Indonesia ideologi "N egara agama" tidak berlaku, tapi itu bukan berarti bahwa semangat untuk menerapkan ideologi itu tidak ada sama sekali. Contoh, ujaran politis dibawakan oleh A min Rais (tokoh agama dalam organisasi Muhamadiya) ketika beliau memberi tausiyah

9 Mircea Eliade, das H eilige und das Profane. Frankfurt am Main: Insel Verlag, 1990, hlm. 13-16. 
di Masjid Baiturrahmin, Mampang Prapatan, Jakarta Selatan pada hari Jumat tanggal 13 April 2018. Beliau berkata:

"Sekarang ini kita harus menggerakkan seluruh kekuatan bangsa ini untuk bergabung dan kekuatan dengan sebuah partai. Bukan hanya PAN, PKS, Gerindra, tapi kelompok yang membela agama Allah, yaitu hizbullah. Untuk melawan siapa? untuk melawan hizbusy syaithan." 10

Demi kepentingan agama, demi kepentingan membela agama Allah, kegiatan-kegiatan keagamaan seperti berbakti di rumah ibadat dijadikan panggung politik. Orang datang untuk berdoa dan menyembah Tuhan, tapi para hadirinnya disusupi oleh ujaran-ujaran politis yang mengganggu kekhusukan berdoa. Tetapi etika beragama yang ditunjuk oleh Pak A min Rais tidak separah dengan etika berpolitik yang ditunjuk oleh para politisi dengan menggunakan agama untuk kepentingan politik. Para politisi yang menggunakan agama untuk kepentingan politik itulah yang disebut sebagai pelaku yang mempolitisasi agama. Di Indonesia justeru merebak politisasi agama secara tidak sehat, bahkan destruktif, karena tingkah laku berpolitik yang menunggang agama tidak diperlihatkan secara beradab dan bermoral. Isu SARA (Suku, Ras, Agama dan Antar-Golongan), khususnya isu agama, yang merebak di tanah air kita sejak kemerdakan Indonesia hingga kini adalah isu politis yang menunggangi agama secara destruktif untuk merebut kekuasaan.Isu ini dihembuskan oleh politisi-politisi untuk meraih kekuasaan. Isu itu memiliki kekuatan destruktif terhadap kehidupan berbangsa dan bernegara, karena menyentuh usaha untuk meniadakan NKRI. Dalam kehidupan berpolitik, isu agama sangat rentan untuk menjadi medan percaturan politik, dan hal ini sangat terbukti dalam kasus A hok pada proses pemilihan gubernur DKI Jakarta pada tahun 2017. Orang menghembuskan fakta kekristenan Ahok dan kasus penodaan agama Islam yang dicapkan pada ujarannya sebagai halangan besar untuk menjabat gubernur DKI. Kekuatan destruktif yang paling berbahaya dalam proses politisasi agama adalah keyakinan religius yang sudah dibentengi secara tak tergoyahkan oleh ideologi religius radikal dan ekstrem seperti ISIS, A lqaida atau era inkuisisi dalam sejarah kekristenan. Bom bunuh diri yang dilakukan oleh sebuah keluarga di tiga gereja di Surabaya pada tanggal 13 Mei 2018 merupakan bukti kuat beroperasinya ideologi religius radikal yang berhasil membentuk keyakinan religius keluarga itu. Bom bunuh diri untuk membunuh lebih banyak orang dipandang sebagai tindakan mati sahid dan masuk surga. Ideologi religius seperti itu masih merupakan problem aktual dunia dewasa ini, terutama bangsa kita yang sedang menjalankan proses deradikalisasi gerakan radikal yang ingin menegakkan pemerintahan khilafah di Indonesia.

10 www.cnnindonesia.com: Amin Rais dikotomikan Partai Setan dan Partai Allah. Diakses ulang pada tanggal 17 Oktober 2018, Pk.19.10. 


\section{Demoralisasi Hukum}

Di dalam Majalah Harian Kompas, Jumat 11 Mei 2018 terdapat artikel yang ditulis ol eh Sudjito A tmoredjo, guru besar IImu Hukum UGM. Judul artikel itu berbuyi "M alapraktik Perundang-undangan". Malapraktek dalam bidang hukum diartikan sebagai peri laku buruk pembuat perundang-undangan dengan akibat bahwa perundang-undangan yang dihasilkan bermasalah. Profesor Sudjito menilai bahwa malapraktek pembuat undang-undang terjadi oleh karena dominasi politik praktis yang mencederai para pembuat undang-undang, apalagi politik uang yang berdampak pada korupsi sistematis yang dilakukan oleh para pembuat undang-undang. Terdapat begitu banyak perundang-undangan yang dibatalkan oleh Mahkamah Konstitusi, Mahkamah Agung atau Kementerian Dalam Negeri.

Di bawah ini ditampilkan beberapa data. Dari tahun 2003 hingga tahun 2018 terdapat 1806 Undang-Undang yang digugat oleh publik, dan perkara pengujian Undang-undang diwenangkan kepada Mahkamah Konstitusi untuk mengujinya. Dari jumlah perkara pengujian itu, terdapat 250 gugatan dikabulkan, 395 ditolak, 349 tidak diterima, 110 gugatan ditarik kembali, 20 gugatan gugur dan 8 gugatan dirasa MK sebagai yang bukan wewenang MK untuk mengujinya. Di MA tercatat tidak kurang dari 142 PP (Peraturan Pemerintah) sepanjang tahun 2015. Dilaporkan MA bahwa PP paling banyak dipersoalkan publik. Dari 72 permohonan yang diterima MA, hanya 19 permohonan dijadikan PP (26,39\%). Pada tanggal 26 Juni 2017, Kemendagri mengumumkan secara resmi pembatalan 3143 Peraturan Daerah (Perda) oleh pemerintah pusat. Alasannya ialah bahwa Perda itu menghambat pertumbuhan ekonomi daerah, memperpanjang jalur birokrasi, serta menghambat investasi dan kemudahan kegiatan usaha. Malapraktek yang ditunjuk data-data ini hanya menyentuh para pelaku pembuat undang-undang, tapi malapraktek juga terjadi pada para pelaku (para hakim dan advokat) yang menerapkan hukum atas kasus-kasus tindakan kejahatan. Salah satu kasus hukum yang menjadi kontroversi publik adalah hukum penistaan agama yang dikeluarkan oleh Sukarno pada tanggal 27 Januari 1965.

Demoralisasi hukum dimaksudkan sebagai pengkudungan atau penyingkiran nilai moral yang seharusnya menjadi darah-daging semua subyek hukum baik para pembuat undang-undang, para penegak hukum, maupun semua warga yang harus berurusan dengan hukum. Nilai moral yang dimaksud adalah elemen moral yang mewujud dalam sifat-sifat atau karakter moral yang melekat kuat pada manusia. Moralitas sebetulnya menjadi tumpuan pijakan semua hukum dan undang-undang, tetapi dalam proses penegakan hukum dan penerapan hukum, subyeksubyek hukum hanya mengacu pada bunyi hukum yang tertulis, karena hukum tertulis itu merupakan kepastian hukum untuk mengukur apakah 
perbuatan seseorang terbukti bersalah melanggar hukum atau tidak. Substansi hukum yang adalah keadilan,kebaikan, kebenaran, kejujuran tidak sepenuhnya terukur dalam pasal-pasal hukum. Pernyataan terakhir inilah yang terjadi di dalam proses penegakan hukum di Indonesia. Moralitas yang dari kodratnya melekat kuat dalam diri semua orang, khususnya dalam subyek-subyek hukum,tidak mungkin terakomodir penuh di dalam pasal-pasal hukum.

Dalam rana filsafat hukum, perlu dicamkan bahwa semua undangundang adal ah bahasa tertulis yang terbatas untuk mengakomodir semua nilai moral. Karakter moral lebih luas dari pada rumusan-rumusan hukum yang secara eksplisit mengakomodir beberapa nilai moral. Betapapun rumusan hukum itu dibuat sangat rinci dalam pasal-pasal nya, betapapun lengkapnya butir-butir yang memuat ketentuan-ketentuan hukum, betapapun banyaknya undang-undang dibuat, selalu saja ada nilai-nilai moral yang tidak terakomodir secara eksplisit dalam rumusan hukum. Di dalam rumusan-rumusan hukum selalu ada cela untuk terjerat hukum atau tidak terjerat hukum. Orang yang tidak memiliki karakter moral dengan mudah menggunakan celah-celah di dalam rumusan-rumusan hukum untuk tidak terjerat oleh hukum, meskipun perbuatannya dengan jelas merupakan perbuatan jahat yang patut dihukum. Karena tidak terakomodir secara penuh di dalam pasal-pasal hukum, maka bunyi pasal-pasal hukum memiliki konsekwensi ganda: melalui pasal tertentu, orang bisa tidak terjerat meskipun perbuatannya jelas salah, tetapi juga orang bisa terjerat, meskipun perbuatannya tidak salah.

Masalah kehidupan berbangsa dan bernegara di bidang hukum adalah masalah nurani kolektif yang belum tertempa. Nurani kolektif adalah kesadaran moral kolektif yang menjadi milik bersama dalam suatu masyarakat. ${ }^{11}$ Nurani kolektif beroperasi melalui kebijakan dan penerapan kebijakan yang bertujuan untuk menggapai kebaikan bersama dan kesejahteraan bersama. N urani kolektif tidak berbentuk, tetapi bersifat merangkul seluruh individu dan kelompok sosial yang berada dalam satu Negara. Nurani kolektif hanya bisa terwujud dalam bentuk dan system kekuasaan tertentu, dan dalam konteks Indonesia nurani kolektif secara formal-yuridis mewujud dalam tiga sistem kekuasaan: legislatif, eksekutif dan yudikatif, tetapi tiga lembaga resmi itu untuk sementara kurang dapat dipercayai oleh rakyat, karena tersandung korupsi, sementara KPK sebagai lembaga ad hoc untuk pemberantasan korupsi boleh dikatakan untuk sementara menjadi bentuk yang masih terpercaya dari perwujudan nurani kollektif.

11 George Ritzer, Teori Sosiologi. E disi Kedelapan 2012. Yogyakarta: Pustaka Pelajar, 2012, hlm. 136-143. 


\section{Tantangan-tantangan Terhadap G ereja Katolik Indonesia Ke Depan}

Perlu dicamkan bahwa tantangan-tantangan terhadap gereja katolik sel alu ada dalam sejarah gereja katolik baik gereja katolik sedunia maupun gereja katolik Indonesia. Tantangannya bermuka banyak dan sangat kompleks. Ada tantangan yang tidak pernah akan hilang dan selalu muncul di sepanjang sejarah keberadaan gereja, seperti Katolik KTP (dipermandikan sebagai katolik tapi tidak pernah kegereja), orang katolik yang imannya seperti benih yang jatuh di atas tanah tandus, di tanah yang bersemak duri, di atas tanah yang berbatu-batu. Tapi ada tantangan yang khas beriringan dengan tanda-tanda zaman seperti gereja katolik di zaman internet sekarang. Di bawah ini dilukiskan dua arah tantangan yang menimpa gereja katolik di Indonesia dewasa ini, yaitu tantangan internal dan tantangan eksternal terhadap gereja katolik. Tantangan internal adalah tantangan yang berasal dari dalam gereja Katolik sendiri terhadap tubuh gereja katolik, dan tantangan eksternal adalah tantangan yang berasal dari luar gereja katolik terhadap tubuh gereja katolik. Untuk melukiskan dua arah tantangan itu, penulis membataskan diri pada tiga masalah yang dilukiskan sebelumnya, dan masalah itu coba ditelusurui dalam konteks internal di dalam tubuh gereja katolik dan konteks eksternal di dalam relasi gereja katolik dengan politik kekuasaan yang dijalankan Negara Kesatuan Republik Indonesia. Pembaca boleh melengkapi lagi tantangan-tantangan lain yang tidak disebut di sini.

\section{Tantangan Internal: D ari G ereja Katolik Indonesia}

A pa tantangan yang dihadapi gereja katolik di Indonesia, tantangan yang berasal dari orang katolik Indonesia? Kenyataan di lapangan menunjukkan bahwa struktur sosial gereja katolik di Indonesia terdiri dari kelompok sosial awam (umat), kelompok sosial biarawan-biarawati, dan kelompok sosial klerus (uskup dan imam). Orang katolik Indonesia yang hanya mencapai sekitar 3\% dari pendudukan NKRI paling banyak didominasi secara kuantitatif oleh kaum awam.

Masyarakat katolik Indonesia dalam statistik gereja katolik pada tahun 2004 terkonsentrasi dalam 6 keuskupan, yang mayoritas penduduknya beragama katolik. ${ }^{12}$

12 www.ekaristi.org/statistik Diakses pada tanggal 29 September 2015 Pk. 15.00. 


\begin{tabular}{|l|l|l|l|}
\hline Keuskupan & \multicolumn{1}{|c|}{ Penduduk } & Umat Katolik & $\begin{array}{c}\text { Persentase } \\
\text { Katolik }\end{array}$ \\
\hline Ende & 712.491 & 693.885 & $97.39 \%$ \\
\hline Ruteng & 637.193 & 615.330 & $96.57 \%$ \\
\hline A tambua & 493.044 & 475.775 & $96.50 \%$ \\
\hline Larantuka & 274.373 & 256.280 & $93.41 \%$ \\
\hline A gats & 77.850 & 45.750 & $58,77 \%$ \\
\hline Sanggau & 530.043 & 265.492 & $50.09 \%$ \\
\hline
\end{tabular}

Sebagai catatan kecil, jumlah umat katolik di keuskupan Malang sebesar 88.255 orang dari total penduduk keuskupan Malang 14.829.884 (sekitar 15 juta) pada tahun 2004; itu berarti hanya 0,60\% dari penduduk keuskupan Malang.

Tantangan terbesar yang berasal dari umat katolik sendiri adalah kemiskinan material. Kemiskinan material meliliti lebih dari dua pertiga jumlah umat katolik, khususnya di wilayah-wilayah keuskupan yang mayoritas penduduknya katolik. Dari pengalaman-pengalaman konkrit di lapangan, kolektehari M inggu di stasi-stasi di desa seperti yang dialami di keuskupan Larantuka tidak sampai 100 ribu rupiah, di pusat paroki antara 100 ribu sampai dengan 500 ribu rupiah. Di Katedral Larantuka, yang umatnya adalah para pegawai negeri dan Cina Katolik, kolekte hari minggu berkisar 6 juta Rupiah. Para Romo yang bekerja di parokiparoki memperoleh honor yang kecil untuk kesejahteraan hidupnya, yaitu sekitar 300 ribu per bulan, sementara biaya pendidikan mereka untuk menjadi imam ditangani seratus persen oleh orang tua mereka yang dewasa ini pada umumnya orang tua pegawai negeri sipil. Tidak heran bahwa kesulitan ekonomi paroki memungkinkan mereka untuk menciptakan kebijakan, peraturan dan tuntutan iuran paroki yang membebankan umat. Birokrasi di paroki dialami sebagai yang membebankan umat. Hidup ekonomis umat Katolik yang bukan pegawai negeri sipil katolik di wilayah-wilayah itu sangat lemah dan boleh dikatakan berada di tingkat kemiskinan hingga tingkat di bawah garis kemiskinan. Jumlah upah minimum perbulan di Kabupaten Flores Timur pada tahun 2000 adalah Rp. 184.000, dan pada tahun 2008 sudah naik menjadi Rp. 650.000 (Keputusan Pemerintah Kabupaten Flores Timur 5 Nopember 2008), sementara pendapatan per kapita untuk para petani dan nelayan sebagai pelaku ekonomi utama tidak sampai rata-rata di bawah satu juta ru- 
piah. Ada tanaman perdagangan seperti kopi, cengkeh, kakao, jambu mente, tapi harga di pasar rendah, sehingga untuk kehidupan pokok saja tidaklah mungkin diandalkan dari hasil perdagangan ini. Dampaknya bisa terbaca, bahwa hidup layak hanya berada di tangan para pegawai negeri sipil yang mendapat gaji tetap dari pemerintah, sementara umat katolik yang bukan pegawai negeri sipil lebih suka pergi merantau ke luar daerah oleh karena beban hidup yang berat. Ketika mereka berada di tanah rantau, mereka membangun komunitas katolik sebagai komunitas katolik yang pada umumnya miskin. Di Paroki Santo A rnoldus Bekasi, umat katolik berjumlah sekitar 27 ribu, dan dari jumlah itu umat katolik yang berasal dari NTT pada umumnya miskin menurut informasi Pastor Parokinya; ada juga umat katolik yang termasuk kelas menengah, tapi jumlah mereka bisa dihitung dengan jari.

Tantangan kedua berasal dari kepincangan relasi antara kaum awam katolik dan para klerus. Di keuskupan yang mayoritas penduduknya adalah umat katolik terbaca juga bahwa ulah dan gaya hidup para klerus menjadi batu sandungan untuk hidup iman umat katolik. Beberapa peristiwa konkrit yang melibatkan para klerus sebagai pejabat gereja berdampak pada terpecahbelahnya umat katolik. Peristiwa yang melibatkan diri uskup misalnya dengan sendirinya menciptakan kubu sosial yang pro uskup (awam katolik dan sebagian para klerus) dan kubu sosial yang melawan uskup (awam katolik dan sebagian para klerus). Isu-isu yang beredar pun menyuburkan kondisi keterpecahan sosial dalam gereja Katolik, ketika kejujuran, keadilan dan kebenaran terbenam dalam politik kekuasaan. Garis kekuasaan yang berada di tangan para klerus dan para awam tidak ditetapkan secara jelas. Misalnya, ada dewan paroki yang merasa bahwa kekuasaannya lebih tinggi dari pastor paroki. Mereka mengambil keputusan sendiri tanpa diketahui pastor paroki. Begitu juga, ada pastor paroki yang tidak memahami dan menghayati secara penuh tugasnya sebagai iman. Jika ada umat yang meminta sakramen minyak suci, pastor paroki berkeberantan dan menunda waktu untuk memberikannya. Dan ada banyak contoh kecil lain lagi yang menyburkan keterpecahan umat.

Tantangan yang berasal dari politisasi yang tidak sehat terhadap agama di kalangan umat katolik ditemukan di dalam praktek-praktek liturgis untuk mengekspresikan iman katoliknya. Setiap perubahan tata tertibliturgis, seperti rumusan dulu "Tuhan sertamu" yang diganti menjadi "Tuhan bersamamu" pada dasarnya, dibangun atas dasar ajaran teologis tertentu - dalam bahasa profan ajaran teologis itu tidak lain dari pada ideologi religius. Perubahan itu berdampak pada praktek iman katolik baik di masa sekarang maupun di masa depan. A da umat katolik yang tidak setuju dengan perubahan itu (kelompok katolik konservatif), ada umat katolik yang sangat setuju dengan perubahan-perubahan itu 
(kelompok katolik liberal), ada umat katolik yang tidak peduli atau acu tak acu (kelompok katolik indifferen), dan ada umat katolik yang mengikuti jalan tengah (kelompok moderat). Praktek-praktek iman katolik tidak mungkin dibangun tanpa keyakinan religius yang disalurkan lewat ideologi religius. Ideologi religius Katolik, yang mencerminkan iman sejati dan spiritualitas hidup katolik,tentu dibangun di atas dasar hidup, perbuatan dan perkataan Yesus Kristus, yaitu semangat cinta kasih, teristimewa mencintai musuh dan mengampuni mereka yang berbuat jahat kepadanya.

\section{Tantangan Eksternal: Tantangan dari luar terhadap tubuh gereja Katolik Indonesia}

Kita boleh membeberkan banyak tantangan yang sedang menimpa dunia ini, termasuk gereja katolik, sekarang dan yang akan datang. A rus globalisasi yang maha dasyat, hedonisme, individualisme, kapitalisme global, teknologi modern yang berisikan hoax, kebencian, terorisme dan narkoba, semuanya merupakan contoh-contoh konkrit yang menjadi tantangan gereja katolik. Tetapi penulis membataskan diri pada tantangan yang berhubungan dengan relasi kekuasaan negara dengan umat katolik di Indonesia. Tiga masalah yang ditampilkan di atas dapat menjadi indikasi betapa kuatnya kekuasaan dari luar gereja Katolik seperti kekuasaan mayoritas atau kekuasaan negara, berdampak pada kehadiran umat katolik di Indonesia.

Dari sisi kuantitas, kekuatan gereja Katolik tak berarti: 3,05\% Katolik dan $96.95 \%$ bukan-katolik. Jumlah yang begitu kecil memberi bayangan kepada orang katolik Indonesia, bahwa ketika berhadapan dengan kekuatan-kekuatan besar yang datang dari luar gereja, lebih-lebih kekuatan yang merugikan gereja katolik, umat katolik pada umumnya harus menderita dan berkompromi dengan kekuatan-kekuatan itu demi keamanan dirinya. Dalam hubungan dengan fenomena proses birokratisasi yang mencekik kehidupan berbangsa dan bernegara, tantangan terbesar terletak di dalam ketidakberdayaan umat katolik untuk membendungnya. Mengapa? Banyak umat katolik adalah bagian hakiki dari proses birokrasi, terutama umat katolik yang berkedudukan sebagai pegawai negeri sipil dan menjabat kedudukan penting di pemerintahan. Bila ada kebijakan-kebijakan dari pusat yang mau diterapkan di lapangan, umat katolik yang berkedudukan sebagai pegawai negeri sipil tidak bisa menolak kebijakan itu, apalagi bila kebijakan itu bersifat "instruktif", meskipun mereka tahu bahwa kebijakan dari pusat itu tidak realistis dan tidak sesuai dengan realitas di lapangan. Contoh, tuntutan penerapan kurikulum 2013 di wilayah-wilayah yang mayoritas kristen. Orang belum terbiasa dan masih belajar untuk menerapkan kurikulum 2006, datang lagi instruksi untuk menerapkan kurikulum 2013. Gereja katolik 
tersandung dalam "ketidakmampuannya" untuk menghadapi kekuatan dan kebijakan dari luar gereja katolik, bahkan orang-orang katolik sendiri dicengkeram oleh penyakit-penyakit sosial bangsa, yaitu KKN yang menghasilkan penyakit korupsi, kekerasan dan kerusakan lingkungan seperti yang disinyalir di dalam N ota Pastoral KWI 2004.

Tantangan terbesar lain adalah korupsi. Salah satu penyakit sosial yang sedang menggerogoti hidup bersama sebagai satu bangsa adalah korupsi yang beruratakar dalam satu gaya hidup cari untung. N ota Pastoral KWI tahun 2017 mengambil judul "M encegah dan M emberantas Korupsi". Gaya hidup cari untung itu menurut bula Paus Fransiskus "M isericordiae Vultus" (Wjah Belaskasih) menghancurkan masa depan orang miskin. Hidup dalam satu sistem ekonomi kapitalis global seperti yang berlaku pada penyelenggaraan ekonomi di Indonesia saat ini (ekonomi pasar bebas), berarti melakukan kegiatan ekonomi gaya cari untung, dan dengan demikian, para penyelenggara negara dari tingkat pusat hingga tingkat desa, termasuk umat katolik yang terlibat dalam penyelenggaraan negara di tiga bidang pemerintahan (bidang eksekutif, legislatif dan yudikatif), tidak luput dari jebakan gaya hidup cari untung. Bukanlah rahasia lagi, bahwa korupsi seperti dilansir dalam media sosial menggerogoti oknum-oknum di bidang eksekutif (bupati, gubernur, kepala desa) yang dipelentir dengan sebutan "eksekuthieves (malingmaling di bidang eksekutif), di bidang legislatif (anggota DPR) yang dipelentir "legislathieves" (maling-maling di bidang legislatif) dan di bidang yudikatif (hakim dan advokat) yang dipelentir "yudikathieves" (maling-maling di bidang yudikatif). Gaya hidup cari untung ini ditopang oleh budaya kolusi, korupsi dan nepotisme yang dihayati manusia Indonesia, termasuk orang katolik hingga era reformasi ini. Malah kaum klerus pun dalam hirarki gereja menghayati gaya hidup cari untung itu, seperti terdengar bahwa bendahara paroki yang adalah romo memboyong dan membawa lari uang kolekte umat.

Tantangan yang berhubungan dengan politisasi yang tidak sehat terhadap agama terletak dalam merebaknya ideologi religius radikal yang membonceng pada agama tertentu. Kita ingat kembali akan zaman inkwisisi yang dilakukan oleh gereja katolik pada abad 16. Inkuisisi gereja katolik Spanyol dipandang sebagai yang paling kejam, karena orangorang yang mengajarkan dan menyebarkan ajaran iman yang bertentangan dengan ajaran resmi gereja katolik diadili, dihukum, dipenjarakan bahkan dibunuh. Yang paling menderita pada waktu itu di Spanyol adalah kelompok Yahudi, sampai Paus Yohanes Paulus kedua harus berdiri di tembok ratapan Yahudi di Yerusalem pada tanggal 21 Maret tahun 2000 untuk berdoa sambil secara resmi mengakui dosa gereja katolik di hadapan orang Yahudi dan memohon pengampunan dari Tuhan atas dosa-dosa gereja secara umum. Dewasa ini Ideologi religius radikal yang paling berbahaya dan belum bisa diatasi adalah bom bunuh 
diri untuk membunuh lebih banyak orang. Dengan perbuatan bunuh diri ini, si pelaku masuk surga dan mati sahid. Itulah keyakinan religiusnya. Mengapa ideologi religius radikal model ini sulit dipecahkan? Ideologi religius seperti itu sudah menjadi darah daging seseorang dan sudah menjadi suatu keyakinan yang mendalam, dan bila keyakinan seperti itu sudah menjadi darah daging seseorang, maka akal budi sehat dikendal ikan oleh keyakinan tersebut dengan akibat bahwa tindakan bunuh diri merupakan konsekwensi logis perintah keyakinan. Untuk orang katolik di Indonesia, ideologi religius radikal yang berbahaya itu dialami sebagai suatu tantangan terbesar, karena gereja katolik dalam disposisi batin penganutideologi religius radikal yang berbahaya model bom bunuh diri adalah musuh yang harus dibasmi.

\section{Menjadi Gereja yang Terlibat Dalam Dunia}

Bagaimana gereja Katolik di Indonesia terlibat di dalam realitas sosial-politik di Indonesia dewasa ini? Pertanyaan ini mengarah kepada pertanyaan tentang "commitment" konkrit masyarakat katolik Indonesia di dalam pergulatan sosial-politik bangsa. Soal visi-misi gereja katolik di dalam pergulatan politik bangsa baik dalam konteks gereja katolik sejagat maupun dalam konteks gereja katolik Indonesia sudah digariskan secara jelas dalam berbagai macam dokumen gereja Katolik, termasuk N ota Pastoral KWI. Di sana disebutkan prinsip-prinsip umum keterlibatan gereja di bidang politik dan dijelaskan spiritualitas etika politik serta makna politik kekuasaan dalam terang injil.

Majalah Hidup edisi 17, tahun ke 72, 29 A pril 2018, memuat edisi khusus dengan judul "Rumah Kader Politik". Sajian utamanya menurunkan artikel "W adah Penggemblengan Kader 'Siap Tempur'. Di sana disebut sebuah lembaga yang diberi nama "VIP" (V ox Populi Institute) dan dikenal dengan nama "VIP" atau Vox Point. Lembaga ini didirikan pada tanggal 12 Maret 2016 di Jakarta dan bertujuan untuk membentuk kader-kader awam katolik yang terpanggil untuk terlibat dalam kegiatan sosial-politik di Indonesia. Kehadirannya dijadikan wadah perhimpunan para awam Katolik yang terpanggil untuk terlibat langsung dalam dunia sosial-politik Indonesia. Dia tidak berafiliasi di bawah salah satu partai politik Indonesia, tetapi anggota-anggotanya bisa datang dari partaipartai politik tertentu. Pemimpin umum VIP sekarang adalah Saudara Yohanes Handojo Budhisejati. Pada tanggal 29 A pril - 1 Mei 2018 dilaksanakan rapat koordinasi nasional pertama di Jakarta. Terhadap kehadiran lembaga Vox Point ini, terdapat banyak reaksi dari awam Katolik yang berkiprah juga di dunia sosial-politik seperti dari PMKRI, dari Bimas Katolik, dari kerasulan awam Katolik, dari tokoh-tokoh katolik sebagai pengamat politik. 
Yang menarik perhatian untuk dicermati pada VIP ini adalah karakter yang melekat pada kadernya, yaitu "siap tempur". Ini menggambarkan satu semangat militan untuk berani berkonfrontasi dengan situasi sosial politik yang menghancurkan kehidupan berbangsa dan bernegara di atas dasar UUD'45 dan Pancasila, berani berkonfrontasi dengan partai-partai politik serta tokoh-tokoh politik yang memperalat agama dan keyakinan religius untuk kepentingan sektarian. Semangat 'siap tempur' ketika diterapkan dalam politik praktis oleh awam katolik berujung pada tindakan atau aksi yang berani mempertaruhkan nyawa untuk melawan segala bentuk kekuasaan yang menindas. Inilah komitmen praktis yang mewujudkan semangat kemartiran. Tapi seorang awam katolik yang pada era Suharto adalah anggota DPR berkata kepada penulis:

“Romo, kami tidak akan melawan kebijakan penguasa, meskipun kami tahu bahwa kebijakan penguasa itu represif, koruptif, kolutif. Kami masih ingat akan anak isteri. Kami hidup dari negara. Kamu para pastor, biarawanbiarawati tidak terikat dengan siapa-siapa. Kalau kamu dibunuh, kamu sendiri saja. Tapi kalau kami dibunuh, anak-isteri kami menderita. Kami tidak mau. Jadi, kami ikut saja akan apa yang digariskan penguasa demi keamanan hidup kami dan keluarga kami."13

Pernyataan tokoh ini menunjukkan bahwa semangat 'siap tempur', meskipun sesuai dengan spiritualitas katolik dalam semangat profetis, tidak sejalan dengan budaya tenggang rasa dan kompromi yang sedang meraja dalam watak bangsa. Korupsi berjemaah adalah cerminan dari budaya tersebut, meskipun bertentangan dengan spiritualitas katolik.

Dalam pengamatan penulis, menjadi gereja yang terlibat dalam dunia secara ideal berarti menjadi garam dunia, menjadi terang dunia, terlibat dalam politik kekuasaan untuk melayani dan bukannya untuk menguasai yang lain, menghayati semangat injili, yaitu menabur cintakasih dan bukannya kebencian. Tetapi secara praktis, menjadi gereja yang terlibat dalam dunia berarti berani berkomitmen dengan semangat 'siap tempur'. Sesewaktu bertindak dan berbicara secara gamblang dan konfrontatif terhadap kekuasaan yang menindas dan diskriminatif, terutama orang kristen di lingkungan yang mayoritas kristendiharapkan harus berani bersikap konfrontatif, bersikap siap tempur. Sikap ini bukan hanya menjadi milik dan tugas awam katolik, tetapi milik dan tugas semua anggota, termasuk para klerus dan biarawan-biarawati.Antara politik dan politik praktis tampak tidak ada perbedaan tajam. Gereja memang

13 Tahun dan tanggal terjadinya percakapan informal antara bapak Almahrum Marsel Beding dan penulis tidak diingat penulis lagi, tapi percakapan itu terjadi di Sankt A ugustin, Jerman, ketika beliau singgah di tempat penulis yang masih belajar di Jerman antara tahun 19911997. 
sudah menggariskan kebijakan resmi, bahwa para klerus, biarawanbiarawati, tidak boleh terlibat dalam politik praktis, tidak boleh berusaha untuk menjadi gubernur, bupati, camat atau kepala desa, tidak boleh berkampanyelangsung untuk partai politik tertentu; mereka harus berdiri netral. Sikap ini juga ditunjuk oleh KWI. KWI selalu bersuara hati-hati, netral, agak takut-takut, berpegang prinsip umum saja agar supaya seruannya yang bersifat moral-konsultatif tidak memecah belahkan bangsa dan tidak membawa konflik dan keresahan masyarakat. Tugas awam katoliklah yang terlibat langsung dalam politik praktis. Bila ada kaum klerus yang terlibat langsung dalam politik praktis oleh karena situasi tertentu yang menuntutnya untuk berpihak dan tidak boleh berdiri netral, maka tindakan mereka dipandang sebagai urusan pribadi dan bukannya urusan gereja.

Tapi dalam konteks Indonesia komitmen awam katolik di Indonesia selalu mengacu pada kebijakan klerus (uskup, imam). Mereka barulah berani bersuara dan beraksi konfrontatif, ketika terjadi penyelewengan kekuasaan para uskup dan imam di dalam tubuh gereja katolik, tetapi bila berhadapan dengan penindasan yang berasal dari luar gereja, kaum awam pada umumnya melirikkan mata ke hirarki dan melihat lebih dahulu bagaimana para klerus bersikap. Bila uskup dan imam bersikap kompromi dan hati-hati untuk menjaga adanya konflik dan perpecahan, kaum awam pun bersikap demikian. Karakter "siap tempur" bukanlah watak bangsa Indonesia, meskipun karakter ini adalah karakter kristiani juga ketika berhadapan dengan kasus-kasus konkrit. Sikap netral, lebih suka berkompromi dari pada berkonfrontasi, tidak memihak, tenggang rasa, tidak ingin berkonflik, sikap-sikap seperti ini ketika berhadapan dengan kasus-kasus konkrit tidak efektif dan berdaya-guna. Karakter siap tempur yang dipromosikan oleh $\mathrm{V}$ ox Point pada hemat penulis haruslah menjadi milik para klerus dan biarawan-biarawati juga.

Komitmen praktis gereja katolik dalam membangun relasi dengan pemerintah sudah disalurkan secara resmi melalui lembaga khusus yang disebut Bimas Katolik. Orang-orang yang bekerja di lembaga Bimas Katolik adalah orang-orang pemerintah dan digaji pemerintah di bawah Kemenag. Dengan demikian di dalam tubuh gereja katolik sendiri tercipta diferensiasi sosial-religius, yaitu ada kelompok sosial katolik pegawai negeri sipil yang bekerja di Departemen Agama dan yang kesejahteraan hidupnya dibiayai negara dan ada kelompok sosial katolik yang bekerja di lingkungan swasta dan yang kesejahteraan hidupnya ditanggung sendiri oleh lembaga swasta. Pada hal, sasaran pelayanan dua kelompok sosial katolik ini (negeri dan swasta) dan bidang pelayanan mereka adalah sama. Sasaran pelayanan adalah umat katolik, sementara bidang pelayanan adalah bidang agama katolik. Tetapi ketika kebijakan publik pemerintah lewat instansi pemerintah seperti Bimas Katolik tidak sejalan 
dengan kebijakan pastoral yang dijalankan oleh instansi swasta atau tumpang tindih, maka proses differensiasi sosial di dalam tubuh gereja katolik bisa membuahkan konflik dan perbenturan sosial di dalam tubuh gereja katolik sendiri.

Dalam situasi seperti yang disebut terakhir, komitmen praktis untuk terlibat aktif dalam dunia sosial-politik bangsa mungkin untuk sementara tidak muncul; gereja berjalan saja seirama dengan gerak-gerak sosial politik pemerintah, meskipun gerak-gerik atau kebijakan pemerintah merugikan eksistensi gereja. Gereja harus berdiam diri untuk menunggu waktu yang tanpan untuk bertindak. Di sanalah ada ruang iman dalam doa, bahwa rahmat Tuhan akan menunjukkan jalan pemecahannya.

\section{Penutup}

Gereja Katolik Indonesia adalah bangsa Indonesia yang beriman katolik. Peristiwa-peristiwa sosial-politis yang terjadi di dalam kehidupan berbangsa dan bernegara Indonesia tentu dialami masyarakat katolik Indonesia. Percaturan politik kekuasaan di tanah air dengan sendirinya melibatkan masyarakat katolik, teristimewa para elite politik dan tokoh agama katolik. Fenomen-fenomen sosial-politis yang mencederai kehidupan berbangsa dan bernegara seperti yang disebutkan di atas menimpa umat katolik Indonesia, dan keadaan seperti itu membuahkan tantangan-tantangan terhadap dirinya baik tantangan yang berasal dari dalam tubuh gereja katolik sendiri maupun dari luar gereja katolik. Terhadap tantangan-tantangan itu, umat katolik Indonesia tetap berpedoman pada kebijakan-kebijakan gereja yang diinspirasikan oleh nilai-nilai injili, yaitu menjadi garam dan terang dunia.

* Sermada K. D onatus

D osen Filsafat di STFT W idya Sasana M alang. Email: donatusse@hotmail.com

\section{BIBLIOG RAFI}

A ristotle, The Politics. London: Penguin Books, 1992.

Eliade, Mircea, das H eiligeund das Profane. Frankfurt am Main: Insel Verlag, 1990.

Fuerstenberg, F, Kirchenform und Gesellschaftsstruktur. Dalam Religionssoziologie. F. Fuerstenberg (Hrsg.). Berlin: Luchterhand, 1970.

Fuerstenberg, Friedrich, Soziologie. Berlin: Walter de Gruyter, 1978.

Habermas, Juergen, The Theory of Communicative Action. Volume Two. Lifew orld System: A 
Critique of Functionalist Reason. Boston: Beacon Press, 1989.

Kaesler, Dirk, M ax W eber Eine Einfuehrung in Leben, Werk und Wirkung. Frankfurt: Campus Verlag, 1995.

Riter, George, Teori Sosiologi. Edisi Kedelapan 2012. Yogyakarta: Pustaka Pelajar, 2012.

Majalah Hidup, Rumah Kader Politik. Edisi 17, Tahun ke-72, 29 A pril, 2018.

Kompas, Senin 30 April 2018.

Kompas, Jumat 11 Mei 2018.

www.cnnindonesia.com: Amin Rais dikotomikan Partai Setan dan Partai Allah. Diakses ulang pada tanggal 17 Oktober 2018, Pk.19.10.

www.ekaristi.org/statistik. Diakses pada tanggal 29 September 2015, Pk. 15.00 .

www.google.com: APBN 2018: Total Anggaran Pendidikan Rp444, 131 Trilliun. Diakses ulang pada tanggal 17 Oktober 2018, Pk. 19,00. 